\title{
SMA Insan Cendekia Madani: Environmentally Friendly School Policy And Implementation Of Environment Based Curriculum As An Ef-Fort In Building Students' Eco-Friendly Character
}

\author{
Jakiatin Nisa $^{1}$, Anissa Windarti ${ }^{1}$, Mirza Desfandi*2, Dan Abdul Mufahir ${ }^{2}$ \\ ${ }^{1}$ Jurusan Pendidikan IPS, UIN Syarif Hidayatullah Jakarta, Tangerang Selatan, \\ Indonesia \\ ${ }^{2}$ Jurusan Pendidikan Geografi, Universitas Syiah Kuala, Aceh, Banda Aceh, Indonesia \\ *E-mail: mirza.desfandi@ gmail.com \\ Received: 14062021 / Accepted: 3006 2021/ Published online: 27072021
}

\begin{abstract}
ABSTRAK
Penelitian bertujuan untuk mengetahui gambaran penerapan pada kebijakan berwawasan lingkungan dalam upaya menumbuhkan karakter peduli lingkungan dan mengetahui tingkat efektifitas penerapan kurikulum berbasis lingkungan da-lam upaya menumbuhkan karakter peduli lingkungan di SMA Insan Cendekia Madani (ICM). Pendekatan penelitian ini adalah Mix Method Research, dengan Strategi Embedded Konkuren, yaitu strategi yang menerapkan satu tahap pengumpulan data kuantitatif dan kualitatif dalam satu waktu. Hasil penelitian menunjuk-kan bahwa: Pertama, gambaran penerapan kebijakan sekolah berwawasan ling-kungan dalam upaya menumbuhkan karakter peduli lingkungan di SMA Insan Cendekia Madani termuat pada Rencana Kegiatan dan Anggaran Sekolah (RKAS); Kedua, tingkat efektifitas Program Adiwiyata pada penerapan kurikulum berbasis lingkungan dalam upaya menumbuhkan karakter peduli lingkungan di SMA ICM dinyatakan Efektif. Berdasarkan temuan penelitian disarankan kepada pihak sekolah untuk menguatkan program sekolah berbasis lingkungan.
\end{abstract}

Kata Kunci: Kebijakan Sekolah, Kurikulum Berbasis Lingkungan, Karakter Peduli Lingkungan

\section{ABSTRACT}

The research aims to determine the description of the application of environmen-tally sound policies in an effort to foster a caring character for the environment and to determine the level of effectiveness of environment-based curriculum im-plementation in an effort to foster a caring character for the environment in ICM Senior High School. The research approach is Mix Method Research, with the Embedded Concurrent Strategy, which is a strategy that implements one stage of quantitative and qualitative data collection at a time. The results showed that first, the description of the implementation of environmental school policies in an effort to foster a caring character for the environment in Insan Cendekia Madani High School is contained in the School Activity Plan and Budget (SAPB). Second, the level of effectiveness of the Adiwiyata Program in implementing an environment-based curriculum in an effort to foster a caring character for the environment in Insan Cendekia Madani High School is declared 
Effective. Based on the research findings, it is suggested to the school to strengthen environment-based school programs.

Keywords: School Policy, Environmentally Based Curriculum, Character Caring for the Environment

\section{INTRODUCTION}

Learning the use of natural resources for development for the welfare of the community provides a very large contribution. On the other hand, reduces the decline in environmental resources, depletes the availability of natural resources and decreases the quality of the environment. The exploitation of resources as a result of modernism (Supriatna, 2016) departs from conventional thinking that places humans as the main actors of history (anthropocentrism) in a linear line of human history. Anthropocentrism views humans as the centre of the universe system. Keraf (2010) explained that this view is, humans and their interests determine the order of ecosystems and policies taken respecting nature, either directly or indirectly. The highest value reference used in this view is people and their interests. Anything that existed in nature was previously considered unfit unless it could be used as a support and for the benefit of humans. Enjoy its nature is only seen as an object (which is subject to). Tools and means for human fulfilment and interests.

Anthropocentrism views that the cause of humans exploiting and depleting the universe to fulfil their interests and needs, without paying enough attention to the preservation of nature. Keraf (2010) explained that the pattern of (human) behaviour that is exploitative, destructive and does not care about nature is considered rooted in a perspective that only emphasizes human interests which gives birth to greedy and greedy attitudes and behaviours that cause humans to take all their needs from nature without considering its sustainability (nature exists only for the benefit of humans).

Human awareness to always care about the environment as part of environmental ethics must continue to be grown, by shifting the conventional perspective from anthropocentrism to a more appropriate perspective (Desfandi, 2015). Every human being must understand that humans were created to be leaders (caliphate) who regulate many things on earth, be it plants, animals, soil, water, air, mountains, forests, and everything on earth to be managed by humans and use them. in a balanced and sustainable manner.

The character of caring for the environment according to the Ministry of National Education, (Research and Development Center for Curriculum, 2010) is "Attitudes and actions that always try to prevent damage to the surrounding natural environment and develop efforts to repair natural damage that has already occurred". As humans, everyone must protect the environment and try to repair the environmental damage that has occurred. With people caring about the environment, the environmental problems that are currently happening will not get bigger, caring for the environment can be done by starting with yourself.

Cultivating the character of caring for the environment is a means to change the perceptions, attitudes and behaviour of students. According to Prayitno et al., (2013) the Johannesburg Summit 2002, expanded the vision of sustainable development and reaffirmed the educational goals in the millennium development goals and education for all that was sparked in the Dakar framework 
for action, and proposed the Decade of Education for Sustainable Development (Decade of Education for Sustainable Development/DESD).

The Adiwiyata program initiated by the Ministry of the Environment aims to encourage and form an environmentally friendly school academic community that can contribute to carrying out environmental conservation and sustainable development efforts. According to the National Adiwiyata Team, the Adiwiyata Program was launched with the hope that every school member was actively involved in school activities to promote a healthy environment and reduce the impact of environmental damage. This program embodies the school's academic community who are responsible for protecting and managing the environment through good school governance to support sustainable development.

To make the Adiwiyata Program a success, it requires seriousness from all parties in implementing and achieving the goals of this program, both from the central level (Ministry of Environment, Ministry of Education and Culture, Ministry of Religion related to Education/Directorate General of Islamic Education, regional level (Provincial and Regency Governments) /city) to the school level.

At the school level, a high commitment from the principal to implement a program is needed in his leadership (Nasution et al., 2018; Suryadi \& Budimansyah, 2016). The role of the teacher is also very important, namely as an educator and as the main driver for students to internalize the values of environmental care. Landriany (2014) describes the results of his research, which are related to the implementation of Adiwiyata policies to realize Environmental Education in Malang City High Schools. The results of Landriany's research indicate that environmental policies in schools have been stated in decrees and are integrated into each subject. Furthermore, still in the study, several obstacles were described that hindered the implementation of the Adiwiyata Program, such as the task force is not on time, limited understanding of the Adiwiyata school concept, funding problems, and problems related to community support and other agencies.

\section{RESEARCH METHOD}

This study uses a quantitative research paradigm, based on the philosophy of post-positivism, which according to (Creswell, 2010) is that symptoms can be grouped, observed, measured, causal, relatively fixed and value-free.

The technique used in this study is a survey (explanatory survey), which is to explain the causal relationship and propose a hypothesis. The main reason for using survey techniques is that surveys can provide accurate, reliable, and valid data from a large number of subjects and a wide range of subjects.

This study examines the effectiveness of the Adiwiyata Program. The effectiveness was tested by analyzing the effectiveness of the implementation of the four Adiwiyata components in each of the recipient schools of the National Adiwiyata in an effort to foster the environmental care character of students. The components of the Adiwiyata program in this study are (1) environmentally friendly school policies and (2) implementation of an environmentally based curriculum. This research design uses the Concurrent Embedded Strategy, which is a strategy that applies one stage of quantitative and qualitative data collection at a time.

\section{Data Analysis}

Quantitative data, analyzed through editing, coding, tabulating, 
Analyzing, Concluding. As for giving value to each question in the questionnaire, the researcher provides the following provisions:

Table 1. Measurement Scale on the Questionnaire

\begin{tabular}{|c|l|c|}
\hline No. & \multicolumn{1}{|c|}{ Level } & Scale \\
\hline $\mathbf{1 .}$ & Never & 1 \\
\hline $\mathbf{2 .}$ & Sometimes & 2 \\
\hline $\mathbf{3 .}$ & Rarely & 3 \\
\hline $\mathbf{4 .}$ & Often & 4 \\
\hline $\mathbf{5 .}$ & Always & 5 \\
\hline
\end{tabular}

The formula used to find the percentage of answers to the questionnaire in each respondent is:

$$
P=\frac{F}{N} \times 100 \%
$$

\section{P: Percentage \\ F: Frequency (Number of respondents' answers) \\ $\mathrm{N}$ : Number of Cases}

After knowing the results of each percentage then the researcher uses the mean formula to find out the average value of the environmental care attitude in SMA Insan Cendekia Madani. The researchers add up each percentage result using the formula:

$$
M X=\frac{\in X}{N}
$$

$$
\begin{aligned}
& \mathrm{Mx}=\text { Mean } \\
& \mathrm{X}=\text { Number of Variables } \\
& \mathrm{N}=\text { Number of cases }
\end{aligned}
$$

Details of the quantitative data analysis used to score the effectiveness of the environmental-based curriculum implementation is done by assigning a score of 1 to 5 for each question item, with a total of 31 statement items, with details of 22 statement items related to the teacher and 9 statement items related to the learners. The lowest score for implementing an environment-based curriculum is 31 and the highest score is 155 with the procedure for determining the category score for the effectiveness of implementing an environment-based

\begin{tabular}{|c|c|c|}
\hline Category & $\begin{array}{c}\text { Effectiveness } \\
\text { Level }\end{array}$ & Average Score \\
\hline I & Effective & $116-155$ \\
\hline II & Less Effective & $74-115$ \\
\hline III & Ineffective & $31-73$ \\
\hline
\end{tabular}
curriculum as follows:

Table 2. Procedure for Determining the Category of Effectiveness of EnvironmentalBased Curriculum Implementation

Source: Primary Data Processing Results, 2020

Data analysis for environmentally friendly school culture goes from a score of 1 to 5 for each question item, with an overall number of statement items 26 . The lowest score for environmentally friendly school culture is 26 and the highest is 130 . The following Table 3 procedures for determining the category of environmentally friendly school culture as follows:

Table 3. Procedure for Determining the Category of Environmentally Friendly School Culture

\begin{tabular}{|c|l|c|} 
Category & $\begin{array}{c}\text { Effectiveness } \\
\text { Level }\end{array}$ & $\begin{array}{c}\text { Average } \\
\text { Score }\end{array}$ \\
\hline I & Strong & $97-130$ \\
\hline II & Less Strong & $62-96$ \\
\hline III & Weak & $26-61$ \\
\hline
\end{tabular}

Source: Primary Data Processing Results, 2020

\section{Qualitative Data}

Data analysis in qualitative research with the steps of the data analysis process, namely: Data reduction (data reduction), Data display (data presentation), Conclusion drawing/verification (drawing conclusions), Data Interpretation, and Conclusions. 


\section{RESULTS AND DISCUSSION}

Environmentally friendly school policies become independent variables that are considered to influence other variables and are not influenced by other variables (applicability of the curriculum, school culture, facilities and infrastructure and environmental care attitude). The response of each respondent is based on a scale which is then from a score of 1 to a score of 5 with a total of 24 items in the questionnaire statement.

The principal of SMA ICM, Dani Mohammad Ramdani, stated that the principal often disseminates the vision and mission of SMA Insan Cendekia Madani which includes efforts to preserve environmental functions and/or prevent pollution and/or environmental damage. This socialization is usually delivered during the flag ceremony on Mondays, during principal and teacher meetings and special activities that the school organizes. This includes always socializing the programs/policies of SMA ICM which include efforts to preserve environmental functions and/or prevent pollution and/or environmental damage.

In addition to the vision, mission and environmentally sound school programs, the curriculum structure is often reminded by principals and vice-principals of the curriculum to include efforts to preserve environmental functions, prevent pollution, and damage to the environment in the components of compulsory subjects in each semester. Writing down efforts to preserve environmental functions, writing down the prevention of pollution and writing down the prevention of environmental damage on the components of compulsory subjects is not continuously written down.

The next sub-indicator of the environmentally friendly school policy is the Insan Cendekia Madani High School Activity and Budget Plan (SAPB). SAPB should ideally always contain environmental protection and management efforts. Insan Cendekia Madani SMA was never included, but overall, the SAPB often included efforts to protect and manage the environment. By frequently including environmental protection and management efforts in the SAPB, there are consequences for the existence of special funds in the allocation of funds, but at SMA ICM it was stated directly by the principal that rarely SMA ICM has a budget for environmental protection and management of $20 \%$ of the total budget of Insan Cendekia Madani High School.

Although SMA ICM rarely has a budget for environmental protection and management efforts of $20 \%$ of the total budget for SMA ICM, there is a special allocation of relatively proportional funds for curriculum development activities, learning activities, student activities, and development of facilities and infrastructure related to environmental protection and management. What is rare and even sometimes there is no allocation of special funds that are relatively proportional for environmental protection and management efforts, namely in activities to increase the capacity of educators and education personnel.

The next environmental school policy that has been implemented by SMA ICM is to establish partnerships in the context of environmental protection and management with various parties. In this indicator, SMA Insan Cendekia Madani only occasionally makes partnerships because of the limited number of parties around the school that can be in line with school policies from an environmental perspective. This occasional partnership is also the same as only occasionally partnerships with other parties for environmental protection and management efforts. In addition to partnerships, the school provides support to the community to improve environmental protection and management efforts in the form of 
technical guidance on making biopori or biogas, waste management and organic farming which is done occasionally.

The last indicator of an insightful school policy is that the school is the person in charge, implementer and supervisor by implementing orderly management and maintenance of school facilities.

Application of Environment-Based Curriculum, based on the results of data collection in the field, the answers to the instrument for implementing an environment-based curriculum range from a score of 1 to 5 for each question item, with a total of 31 statement items, with details of 22 statement items related to teachers and 9 related statement items to students. The lowest score for the implementation of the environment-based curriculum is 31 and the highest score is 155. The results of the scoring of the implementation of the environment-based school curriculum aimed at teachers are 92. The total score for the implementation of the environment-based school curriculum is 129. As for the procedure for determining the effectiveness of the implementation of the environment-based curriculum. the environment can be seen in Table 4 below:

Table 4. Procedure for Determining the Effectiveness of Curriculum Implementation Environment Based

\begin{tabular}{|c|l|c|} 
Category & \multicolumn{1}{|c|}{$\begin{array}{c}\text { Effectiveness } \\
\text { Level }\end{array}$} & $\begin{array}{c}\text { Average } \\
\text { Score }\end{array}$ \\
\hline I & Effective & $116-155$ \\
\hline II & Less Effective & $74-115$ \\
\hline III & Ineffective & $31-73$ \\
\hline
\end{tabular}

Source: Primary Data Processing Results, 2020

Based on the results obtained from the sum of the scores for the implementation of the environment-based school curriculum, it is in category I, which means that the implementation of the environmental-based school curriculum is Effective in the Adiwiyata
Program to foster the environmental care character of students. On the indicators of implementing an environment-based curriculum, in several subjects, such as Biology and Geography, the development of a syllabus for learning related to the environment. According to Upi Fitriani, a Biology teacher, stated in an interview that: "In the past two years, biology itself has been Cambridge, sir, so the syllabus automatically uses the Cambridge syllabus. But for myself, at that time, the national curriculum or otherwise, I always developed environmental points because that was part of Adiwiyata too. But actually, in the Cambridge syllabus itself, there are already topics or learning indicators that do refer to environmental education, for example, if at Cambridge this biology material is different from the national one, yes, there is material about smoking (smoking), then human population, associated with carrying capacity of the environment, it indirectly connects it with the environment."

The development of learning indicators related to environmental protection and management at SMA ICM underwent two phases. The first phase, each subject teacher still applies the national curriculum, then the second phase, the pure teacher applies the Cambridge curriculum. Entering this second year, SMA ICM is in the initial phase with the national curriculum in class $\mathrm{X}$ with material related to ecosystems and nature protection. The next material is related to conservation through national parks, followed by local and global conservation. The development of learning indicators related to environmental protection and management at SMA ICM continues until class XII with language composting.

Environmentally-minded school policies in SMA ICM take an integrated approach, which does not directly include Environmental Education subjects in the 
curriculum, but efforts to preserve environmental functions, prevention efforts such as the occurrence and damage to the environment are inserted into compulsory subjects Geography, Biology, Chemistry. The application of a curriculum interaction approach, such as SMA ICM, supports effectiveness or success in efforts to foster environmental care characters because Environmental Education is an interdisciplinary subject, as stated by (Hungerford, 2009 ; Desfandi et al., 2017) "environmental education as an interdisciplinary effort aimed at helping learners gain the knowledge and skills that would allow them to understand the complex environmental issues facing, society, as well as the ability to deal effectively and responsibly with them.

Hungerford's opinion states that Environmental Education can be linked to various other sciences but still to achieve the same goal. The unification of material related to the environment in other subjects is aimed at fostering the character of caring for the environment in students.

In implementing the curriculum with an integration approach (unification in other subjects), the teacher collaborates with teachers who teach the same subject or with teachers who teach different subjects. According Desfandi et al., (2019); Ertekin \& Yüksel, (2014) research suggests that it is better for teachers to teach a subject with teachers in other subjects, such as biology teachers to work together with geography teachers in an effort to change students' attitudes and behavior related to the environment in learning Environmental education interdisciplinary.

The results showed that in SMA ICM the School Activity Plan and Budget (SAPB) had included environmental protection and management efforts, meaning that the school had provided a special budget for environmental protection and management efforts. In terms of budgets for developing curriculum and learning, from field meetings, at schools, budgets for environmental protection and management have been allocated to develop curricula and learning activities related to the environment, such as to provide teaching materials, provision of tools and practice materials. The availability of sufficient budget allows schools to freely develop and carry out adequate learning activities.

Therefore, to realize students who care about the environment in schools, a serious effort is needed between all components including the efforts of the principal, the active role of school residents and community support (Azmi \& Elfayetti, 2017 ; Desfandi et al., 2017).

\section{CONCLUSION}

Based on the results of the research and discussion, conclusions can be drawn: First, an overview of the implementation of the Adiwiyata Program on environmentally friendly school policies. The Adiwiyata Program in an effort to foster environmental care characters in SMA ICM, namely, including the socialization of the vision and mission, curriculum structure, compulsory subjects, School Activity Plan and Budget (SAPB), school budget allocations, school partnerships, school support, schools being resource persons and providing support for environmental protection as a whole are carried out well in a participatory manner and involve the participation of all school members and partner agencies related to environmental management.

Second, the level of effectiveness of the Adiwiyata Program in the application of an environmentally-based curriculum in an effort to foster environmental care character in SMA ICM is declared Effective, which means that the application of an environmentally-based school curriculum as part of the Adiwiyata Program is Effective in an effort to foster 
environmental care character of students. Category 1 (Effective) level. Based on these results, the authors suggest to other schools to be able to strengthen environmentally friendly school policies by implementing practical policies that directly involve the entire school academic community to care more about the environment. Then, strengthening the implementation of an environment-based curriculum in schools can be through teachers as educators who act as facilitators in learning so that they can become models for students to behave and have environmental care skills.

\section{REFERENCE}

Azmi, F., \& Elfayetti, E. (2017). Analisis Sikap Peduli Lingkungan Siswa Melalui Program Adiwiyata Di SMA Negeri 1 Medan. Jurnal Geografi, 9(2), 125-132.

Creswell, J. W. (2010). Research design pendekatan kualitatif, kuantitatif, dan mixed. Yogyakarta: Pustaka Pelajar.

Desfandi, M. (2015). Mewujudkan masyarakat berkarakter peduli lingkungan melalui program adiwiyata. SOSIO-DIDAKTIKA: Social Science Education Journal, 2(1), 31-37.

Desfandi, M., Maryani, E., \& Disman, D. (2019). Implementation of Adiwiyata Program in the Effort to Create Environmental Cultured School in Banda Aceh. Sumatra Journal of Disaster, Geography and Geography Education, 3(2), 1-8.

Desfandi, M., Maryani, E., \& others. (2017). Building ecoliteracy through adiwiyata program (study at adiwiyata school in Banda Aceh). The Indonesian Journal of Geography, 49(1), 51.

Ertekin, T., \& Yüksel, Ç. (2014). The role of ecological literacy education with academic support in raising environmental awareness for high school students:"Enka ecological literacy summer camp project case study." Procedia-Social and Behavioral Sciences, 120, 124-132.

Hungerford, H. R. (2009). Environmental education (EE) for the 21st century: Where have we been? Where are we now? Where are we headed? The Journal of Environmental Education, 41(1), 1-6.

Keraf, A. S. (2010). Etika lingkungan hidup. Penerbit Buku Kompas.

Landriany, E. (2014). Implementasi kebijakan adiwiyata dalam upaya mewujudkan pendidikan lingkungan hidup di SMA Kota Malang. Jurnal Kebijakan Dan Pengembangan Pendidikan, 2(1).

Nasution, N. B., Karimah, S., Studi, P., Matematika, P., \& Pekalongan, U. (2018). Analisis pengetahuan awal mahasiswa mengenai masalah intrusi air laut dan rob. 15, 1-7.

Prayitno, Y., Djati, M. S., Soemarno, S., \& Fanani, Z. (2013). Pendidikan Berperspektif Lingkungan Menuju Pembangunan Berkelanjutan. Wacana Journal of Social and Humanity Studies, 16(1), 41-51.

Research and Development Center for Curriculum. (2010). Pengembangan dan Pendidikan Budaya Karakter Bangsa. Jakarta: Badan Penelitian dan Pengembangan Pusat Kurikulum Kemendiknas.

Supriatna, N. (2016). Ecopedagogy: Membangun kecerdasan ekologis dalam Pembelajaran IPS. Bandung: PT Remaja Rosdakarya.

Suryadi, A., \& Budimansyah, D. (2016). Advance School Leadership, Progress Teaching Approach and Boost Learning: The Case of Indonesia. The New Educational Review, 45(3), 76-87. 